\title{
Relationship among Capital Regulations, Risk and Efficiency: Comparison of Islamic with Conventional Banks in Pakistan
}

\section{Adnan Bashir* and Arshad Hassan**}

\begin{abstract}
This paper examines and compares the relationships between capital regulations, risk and efficiency of Islamic banks with conventional banks in Pakistan from 2003 to 2015. By employing seemingly unrelated regression (SUR) this study finds that capital regulations have no significant effect on the risks taken by Pakistani Islamic banks. Capital regulations have increased the operational efficiency, while it has neither decreased nor increased the cost efficiency of the banks. The results of this study find no major difference in the capital regulations, risk and efficiency relationships between Islamic and conventional banks. The findings of this study also highlight the significant difference in the effect of capital regulations on the bank risks before and after the Global Financial Crisis of 2008, while there is no difference in the impact of capital regulations on bank efficiency before and after the 2008 crisis.
\end{abstract}

Key words: Capital regulations, bank efficiency, bank risk, Islamic Banking, Conventional banks, Global Financial Crisis.

JEL Classification: C39, G18, G21, E58

\section{Introduction}

\subsection{Background of the Study}

The failure of banks during last few decades underlines the major risks associated with banking (Vianney, 2013), and uncovers the requirement for sound legal framework to minimize future risks connected with banking. The response of governments and bank regulators to these bankruptcies came in the form of strict regulations for banks. However, according to Barth, Caprio and Levine (2006) the impact of regulation and monitoring on the bank is not clear. They explained two conflicting views.

\footnotetext{
* Assistant Professor, University of Gujrat, Gujrat, Pakistan. Email: adnan.bashir@uog.edu.pk.

** Dean, Capital University of Science \& Technology, Islamabad, Pakistan. Email: arshad@ cust.edu.pk.
} 
The first, public interest view, states that for the sake of safety of the common man government plays its role by regulating banks to encourage efficient banking practices to alleviate market malfunctions. The main rational of this theory is to protect the common man from malpractices and misconduct in the market place e.g. imperfect competition, monopolies and unbalanced market operations. The hidden logic of this public interest theory is that regulation is necessary to make businesses or organizations work in the interest of the common man. Baldwin, Cave and Lodge (2012) describe the regulations under public interest view as the helping hand of the common man against self-interest groups of individuals or firms. To achieve its aim of protecting the public, regulators try to provide all the information needed for decision making. By contrast, the private interest view purports that rules are enforced to accommodate selected personnel, instead of the public. Stigler (1971) states that regulated industries pressurize the regulator to change laws to protect their interests. Though public interest view stresses the role of government to correct market failures, the private interest view cites the aspiration of politicians and government regulators to increase their own benefit with market failures. This theory also states that due to its discretionary power, regulators can shape banking guidelines, where private interest of groups will dictate the public interest. The Basel Committee was formed by the G-10 (ten largest economies in the world) to analyze the failure of Herstatt Bank and it came up with three recommendations known as Basel I, II and III. Although Basel accords are implemented by almost all the countries of the world, there is no consensus on the effectiveness of these accords.

The unparalleled international financial turmoil after the Global Financial Crisis raised serious questions on the working of conventional banking. Due to disagreement on the effectiveness of the Basel regulations, people are raising questions about the ability of conventional banking to address the dangers it produced. According to Miah and Sharmeen (2015) both practitioners and academicians are questioning the ability of the conventional banking mechanism to overcome the risks caused by conventional banking. They are of the view that the scholars are now focusing on Islamic banking as a competitor rather that an alternative to conventional banking. According to Bitar (2014), the Profit and Loss Sharing (PLS) feature of Islamic banking plays a pivotal factor in its popularity. Since these banks share their profit and loss with their customers, they are extra vigilant in their investments, unlike conventional banks, due to fear of loss of clients in circumstances of high losses. 


\subsection{History of Banking and its Regulation in Pakistan}

The State Bank of Pakistan (SBP) has taken different initiatives for the promotion of Islamic banking since 1947. However, for the introduction of Islamic banking, the Pakistani government took a number of steps between 1979 and 1992. During this time, the concept of interest free Islamic banking was introduced. Issuance of the Zakat and Ushr Ordinance, establishment of Mudarbaha companies and launching of Participatory Term Certificates (PTC) also occurred during 1980. Moreover, in 1981 state-owned banks were bound to provide clients interest-free services and facilities. The year 1984 saw an amendment in the Banking and Financial Services Ordinance by incorporating non-interest based systems. However, according to Awan (2009), the growth of Islamic banking in Pakistan has accelerated since 2002. The Supreme Court of Pakistan instructed the government of Pakistan to bring its financial system in line with Shariah by making necessary changes in current financial structure. To conform to the decision of the Supreme Court, in December 2001 the State Bank of Pakistan took several steps. It issued comprehensive criteria to establish proper commercial private Islamic banks. In January 2002, the State Bank of Pakistan issued the complete Islamic Bank license to Meezan Bank Limited and it became the pioneer Islamic commercial bank in Pakistan. Different task forces were set up to eradicated interest from Government financial transactions and to change the legal framework to Islamic principles. In 2003, the State Bank provided comprehensive guidelines for establishing affiliates and separate Islamic banking offices by conventional banks. Over the years, Islamic banking in Pakistan has shown reasonable growth. According to Ayub and Javeed (2016), the Pakistani Islamic banking sector has seen a growth rate of 11 percent per annum in its assets, while that of worldwide Islamic financial services witnessed a 7.3 percent growth in 2015. The time period of this growth of Islamic banking in 2002 coincides with the consolidation phase of financial sector reforms i.e. 2002 to 2004. The State Bank of Pakistan started the consolidation process of the banking industry by increasing the limit of regulatory capital for banks (Khan \& Khan, 2007). Banks were encouraged to make independent companies to work as mutual funds and asset management companies. Moreover, banks were instructed to increase their loaning to mediocre and poorer segments of society. Special focus was given to Automation and Prudential Regulations. Banking audit, monitoring and corporate governance is also given due weightage and is taken great care of. 
Several contributions are made by this study to the empirical literature. Examination of the relationships between capital regulations, efficiency and risk by using multiple proxies in the Pakistani banking industry is the first contribution of this research. Comparison of the regulatory capital, risk and efficiency nexus with respect to commercial banks of Pakistan (Islamic with conventional) marks the second contribution of this study. Investigation of this relationship with respect to Islamic banks in the pre and post Global Financial Crisis period represents the third contribution of this study. According to de Guevara, Maudos \& Pérez (2007), there are very few studies examining the relationship of capital regulation with efficiency and risk in an Asian context. There is a gap in the previous studies that investigated this relationship in the Pakistani banking sector generally and Pakistani Islamic banks specifically. The results of this research will help the State bank of Pakistan assess the effectiveness of the Basel capital regulations on the banking sector in general and on Islamic banks in particular. It will help the State bank of Pakistan in formulating and enforcing suitable policies and strategies regarding risk and efficiency with respect to both conventional and Islamic banks.

\section{Literature Review}

\subsection{Capital Regulations Effect on Bank Risk}

In theory there are two schools of thought regarding the effect of capital regulations on bank risk. One school of thought supports the positive effect of capital and risk (Kim \& Santomero 1988). As banks take more risk, they increase their capital significantly to mitigate the effect of bankruptcy due to the pressure of the state bank. However, theory also advocates the inverse association between capital and risk. The presence of the flat deposit insurance scheme can be cited as a major reason for the negative link between the two (Furlong \& Keeley, 1989). They argued that the presence of deposit insurance schemes allows banks to incur more risks without increasing their bank capital.

Risk and capital level changes had a positive impact on each other in US bank holding companies (Shrieves \& Dahl 1992). They also established that risk exposures and capital levels were simultaneously determined. Supervisory pressure did not influence risk, while it positively influenced capital (Rime, 2001). Rime (2001) observed that between 1989 and 1995 Swiss banks incre ased their capital ratios to avoid the penalties for not maintaining required capital regulations. Hassan and Hussain 
(2006) concluded that a country's environmental, legal and cultural features should be considered while designing capital regulation policies. By looking at the influence of regulations on bank behavior Hassan and Hussain (2006) noted that in countries with less developed financial systems, capital ratios and portfolio risk were inversely related. Awdeh, El-Moussawi and Machrouh (2011) concluded a positive impact of capital regulations on risk. They also observed a positive correlation between bank profitability and increase in capital, thus seconding the use of retained earnings to increase capital rather than issue new equity. Tan and Floros (2013) looked at link between risk and capital on 101 commercial banks of China by applying three staged least estimation. Their findings supported a negative relationship between risk and capital. Alam (2013) found a positive influence of capital regulation on technical efficiency, while it has an inverse relationship with Islamic banks risks. A positive association between capital and risk for Islamic banks was found by Miah and Sharmeen (2015), while with regards to conventional banks in their study, there was no significant relationship between capital and risk. In their study on commercial banks of Pakistan from 2005 to 2012, Ashraf, Arshad, and $\mathrm{Hu}$ (2016) favored the notion of forcing banks to higher capital requirements as it forces them to reduce risk. They cited lack of regulatory arbitrage opportunities for reducing the asset portfolio risk. Bashir and Hassan (2017) differentiated the effect of Basel I and II capital regulations on the risk of Pakistani commercial banks from 1997 to 2015. They were of the view that Basel II capital regulations were more effective than Basel I in reducing risks of banks.

\subsection{Capital Regulations Effect on Efficiency}

There is disagreement about the influence of capital regulations on bank efficiency. Those who believe there to be a negative relationship are of the view that increased efficiency is a signal of low bankruptcy (Repullo \& Suarez, 2008). This means banks can retain less capital as it has little chance of bankruptcy due to high efficiency. Those advocating a positive relationship are of the view that high efficiency allows banks extra income to maintain high capital ratios to overcome the possibility of bankruptcy (Pasiouras, Tanna, \& Zopounidis, 2009).

Barth, Caprio and Levine (2008) challenged the notion of forcing banks into regulations for the sake of improvement in efficiency as they failed to find any evidence of it in their cross-country study involving banks in 142 countries. Pasiouras et al. (2009) reported mixed results in their sample. Strict capital regulations decreased the profit efficiency while 
it increased the cost efficiency. Delis, Molyneux and Pasiouras (2011) noted that overall capital requirements and supervision by the central bank had no effect on the efficiency of the banks in their sample. The only exception to this is the period after the Global Financial Crisis. Chortareas, Girardone and Ventouri (2012) were of the view that regulations reduce the efficiency of financial institution. They reported that regulation plays a positive role in the efficiency of the transparent and democratically strong countries. Barth et al. (2013) noted that strict capital regulations played a minor positive role in enhancing the efficiency of the banks functioning in seventy-two countries during the period from 1999 to 2007. Bouheni (2013) concluded that the effect of regulatory supervision on the performance of the banks varies according to country and institutional environment. He arrived at his findings by exploring the impact of banking supervision on the performance of the 10 largest banks of France, Germany, UK and Greece during the period of 2005 to 2011. Pessarossi and Weill (2015) observed that the cost efficiency of Chinese banks increased after the implementation of capital regulations. They found a positive impact of capital ratio on cost efficiency. They were of the view that the increase in cost efficiency was dependent on the ownership type of bank. Triki, Kouki, Dhaou and Calice (2017) looked at the effect of different regulatory activities on 46 African countries banks efficiency. They reported mixed findings. Some activities affected the efficiency while others did not. They were of the view compliance to strict capital requirements should not be used as punishing tool against small bank. They concluded that bank should follow the regulations according to their size and risk level.

\subsection{Association of Risk and Efficiency}

Theory offers different justifications about the risk and efficiency nexus. To boost their profits, banks can choose to lower their costs in the short term. By incurring small costs, non-performing loans are unaltered in short term. This positive relationship of risk and efficiency is called the skimping hypothesis. Those in support of a negative relationship argue that banks having little efficiency due to poor management, or external events beyond the control of management will incur more cost. This will decrease their efficiency, and the low efficiency banks need to incur high risks to reimburse the effects of inefficiency. This negative relationship is called bad management or the bad luck hypothesis (Berger \& De Young, 1997).

Altunbas, Liu, Molyneux, and Seth (2000) explored the effect of risk on cost efficiency and in their sample of Japanese commercial banks during the period of 1993 to 1996. They reported that risk has a negative 
relationship with efficiency that efficiency allows cushion to evaluate risk. They reported that risk has a negative relationship with efficiency in their sample of Japanese commercial banks during the period of 1993 to 1996. Das and Ghosh (2004) were of the view that efficiency had a positive effect on the credit risk in their sample of Indian banks. He argued that efficiency allows flexibility to take on more risk. Their findings supported the notion that capital, efficiency and risk are jointly determined and should not be treated separately. Podpiera and Weill (2008) observed a negative association between risk and efficiency in 43 Czech banks from 1994 to 2005. Sun and Chang (2011) reported a negative relationship between credit and operational risk with cost efficiency. In their study of banks in eight emerging Asian countries from 1998 to 2008, the impact of market risk on efficiency was positive. Nguyen and Nghiem (2015) reported that there was considerable difference in the risk and efficiency relationship of public and private banks. Sarmiento and Galán (2017) noted that size was an important factor in the risk and efficiency relationship of 31 Columbian commercial banks for the period of 2002 to 2012. They observed that large and foreign banks take more risk.

\subsection{Hypotheses}

Based on above literature review, following hypotheses have been developed for testing in this study.

H1A: Bank risk decreases with bank capital regulations.

H2A: Bank efficiency decreases with capital regulations.

H3A: Bank risk decreases with bank efficiency.

\section{Methodology}

\subsection{Data and Sample}

All listed Islamic and conventional banks from 2003 to 2015 in Pakistan constitute the sample of this research. The list of all pure Islamic banks was obtained from the Islamic Bank Department of the State Bank of Pakistan. According to the Islamic Banking Bulletin (2015), there were five complete Islamic banks in 2015, majority were conventional banks with Islamic windows (hybrid). Banks with complete data in all variables for the particular year are included in the study. A similar selection procedure is 
used in the case of conventional banks. Financial statements of particular banks are used as the data source.

\subsection{Measurement of Variables}

\subsubsection{Bank Risk}

The proxy for bank risk used in this study is the loans loss provision to net interest revenue ratio, as per Reda, Rjoub and Alrub (2016). It is a measure of quality of the loans of a bank. A low value of this ratio indicates that provision for losses incurred with respect to interest revenue (net) is low and hence risk is low.

\subsubsection{Bank Efficiency}

Bank efficiency is measured by net interest margin (NIM) as per Dumičić and Ridzak (2013). This proxy of efficiency is calculated by dividing the net interest income of a bank to its average earning assets.

\subsubsection{Bank Capital}

For bank capital regulations, the total risk weighted assets of a bank divided by the sum of tier 1 and tier 2 capital (TCTR) is used as per Jacques and Nigro (1997).

\subsubsection{Size}

Another control variable used in this study is size. The natural log of total assets for a bank is used to compute this variable. Miah and Sharmeen (2015) and Alam (2013) also propose this proxy.

\subsubsection{Return on Average Asset}

In order to measure the profitability of bank, return on average assets (ROAA) is employed. It is calculated by dividing the net income of a bank to its average total assets as proposed by Popovici (2014) who has employed this proxy in his research.

\subsubsection{Net Loans to Total Assets}

The liquidity of the banks is captured by using net loans to total asset (NLTA) as used by Alam (2013). It is calculated by dividing the net loans made by the bank by its total asset. 


\subsection{Empirical Model and Estimation Techniques}

The existing literature suggests the presence of endogenity among the bank capital, bank risk and bank efficiency because these three variables are determined simultaneously. Previous studies have used different methodologies e.g. instrumental variable (IV), generalized methods of moments (GMM) and robust standard error estimators for panel models (PCSE).

\subsubsection{Seemingly Unrelated Regression (SUR)}

Due to the small number of observations in the case of Islamic banks, other techniques such as GMM cannot be used. Seemingly unrelated regression (SUR) also becomes a suitable estimation technique due to non-availability of suitable instrumental variable (IV) to be used in 2sls and 3sls. The link between the three variables risk, capital and efficiency is estimated by specifying a scheme of equations and making use of Zellner's (1962) methodology. By doing so, this study has followed the methodology used by Altunbas, Carbo, Gardener and Molyneux (2007), Miah and Sharmeen (2015). This estimation method is not extensively applied in Pakistani banking regulation research.

$$
\begin{aligned}
& \text { LLPNIR }_{\text {it }}=\alpha_{0}+\beta_{1} \text { TCTR }_{i t}+\beta_{2} \text { NIM }_{i t}+\beta_{3} \text { NLTA }_{i t}+\beta_{4} \text { SIZE }_{i t}+\beta_{5} \text { ROAA }+\varepsilon i \\
& \text { NIM }_{i t}=\alpha_{0}+\beta_{1} \text { TCTR }_{i t}+\beta_{2} \text { LLPNIR }_{i t}+\beta_{3} \text { NLTA }_{i t}+\beta_{4} \text { SIZE }_{i t}+\beta_{5} \text { ROAA }_{+1} \\
& \text { TCTR }_{i t}=\alpha_{0}+\beta_{1} \text { LLPNIR }_{i t}+\beta_{2} \text { NIM }_{i t}+\beta_{3} \text { NLTA }_{i t}+\beta_{4} \text { SIZE }_{i t}+\beta_{5} \text { ROAA }_{i t}+\varepsilon i
\end{aligned}
$$

\section{Empirical Results}

\subsection{Descriptive Statistics}

Descriptive statistics of all the variables studied are reported in Table 1. The upper and lower parts of Table 1 display the descriptive statistics for Islamic and conventional banks respectively. Results show that estimated provision for losses expressed as a percentage of net interest revenue of the Islamic banks in this study is 9.83 percent. The minimum and maximum value of the measure of asset quality for Islamic banks stands at -22.36 percent and 80.97 percent respectively. The average value of NIM is 4.89 percent and its value falls between a minimum of 1.60 percent and maximum of 8.64 percent. Table 1 also shows that the average TCTR of the Islamic banks in the sample is 22.24 percent, which far exceeds the regulatory requirements of $8.00 \& 10.5$ percent. The value of this ratio 
ranges from minimum of 9.58 percent to maximum of 62.01 percent. The average value of NLTA stands at 47.36 percent; while it's high and low values fluctuate from 26.60 per cent to 66.81 percent approximately. The average ROAA of banks is weak at 0.18 percent and some banks suffer losses as depicted by the minimum value of -12.29 percent and maximum ROAA stands at 4.94 percent roughly. Similarly, another bank specific variable size is reported in table 1 as well.

The latter part of Table 1 displays the descriptive statistics for conventional banks. Here Loans Loss Provision to Net Interest Revenue (LLPNIR) has seen a rise in the average value to 23.87 percent. Its highest and lowest values are also showing an upward trend. Average value of Net Interest Margin has decreased to 3.78 percent from 4.89 percent of Islamic banks. Similarly, average value Total Capital to Total Risk Weighted Assets has also decreased to 15.23 percent, though it is still considerably above regulatory requirement. The average value of NLTA is showing a small decrease in conventional banks at 45.73 percent approximately. The size and ROAA of conventional banks are showing an upward trend from their Islamic counterparts.

Table 1: Descriptive Statistics

\begin{tabular}{lcccccc}
\hline \multicolumn{7}{c}{ Islamic Banks } \\
\hline Mean & LLPNIR & NIM & TCTR & NLTA & SIZE & ROAA \\
Std. Dev & 9.83 & 4.89 & 22.24 & 47.36 & 10.55 & 0.18 \\
Minimum & 18.52 & 1.70 & 13.60 & 11.38 & 1.14 & 2.37 \\
Maximum & -22.36 & 1.60 & 9.58 & 26.60 & 8.30 & -12.29 \\
\hline \multicolumn{7}{c}{ Conventional Banks } \\
\hline Mean & 80.97 & 8.64 & 62.01 & 66.81 & 13.18 & 4.94 \\
Std. Dev & 23.87 & 3.78 & 15.23 & 45.73 & 11.57 & 0.56 \\
Minimum & 95.86 & 1.87 & 9.38 & 11.29 & 1.43 & 1.95 \\
Maximum & -395.63 & -1.45 & 0.08 & 10.05 & 7.85 & -9.22 \\
\hline
\end{tabular}

*Values rounded off to two decimal places

\subsection{Impact of Capital Regulation on Bank Risk}

Table 2 explains the impact of capital regulation on the risk of the Islamic banks. According to the findings of this study, the coefficient of bank regulatory capital has a negative impact on the credit risks of the Islamic banks, but the relationship does not reach significance. The results of this 
study show that capital regulations have no effect on the risk taking of Islamic banks. Here findings of the study reject H1A. As far as the effect of bank efficiency on the risk-taking behavior of banks; here NIM has a negative effect on the risks of the Islamic banks. So, banks with high operating efficiency see a decrease in the risk of the Islamic banks, as a high value of NIM is a sign of greater efficiency. These results support H3A and support the bad management hypothesis. This hypothesis states that the efficiency of a bank is reduced with management incompetency. Banks with less efficiency due to poor management will become involved in riskier activities to reimburse the effect of their inefficiency. Here results of this study follow those of Nguyen and Nghiem (2015). However, the NLTA ratio has a significant and negative effect on the bank risk. This shows that as banks' liquidity increases, its risks decrease and vice versa, since a high NLTA ratio is a sign of low liquidity. One possible argument put forward for this is due to less liquidity, the funding cost of banks may be increased which in turn increased the risks of the bank. The impact of liquidity ratio may be negative. These findings are consistent with the findings of Tan and Floros (2013). Size and ROAA do not affect the risk of the banks in this study.

Table 2: SUR Regression of Risk Equation with LLPNIR as dependent variable

\begin{tabular}{lcc}
\hline Variable & Coefficient & SE \\
\hline TCTR & -0.3379 & 0.3588 \\
NIM & $-4.4342^{* * *}$ & 1.6004 \\
NLTA & $-0.5233^{*}$ & 0.2949 \\
SIZE & -4.3516 & 3.5755 \\
ROAA & -2.1051 & 1.3096 \\
No. of observations & 45 & \\
Parameter & 5 & \\
RMSE & 17.099 & \\
R Square & 0.1281 & \\
Chi Sq & $15.53^{*}$ & \\
\hline
\end{tabular}

$* * *, * *, *$ Significant at the $1 \%, 5 \%$, and $10 \%$ levels

To make results generalizable, the impact of capital regulations on another proxy of risk, non-performing loans to gross loans (NPLGL) is studied and results are reported in Table 3. Results show that capital regulations do not have a significant effect on the risks of the Islamic banks, indicating that H1A should be rejected. NIM has a negative effect on the risks of Islamic banks thus accepting H3A hypothesis. Liquidity negatively 
affects the risk considered by the banks because the NLTA ratio has a negative coefficient. Size has positive and significant effect on the banks in our sample. The results show that the big banks take more risk than their small counterparts. One possible explanation might be that size allows flexibility to overcome the possibility of defaults, so big banks indulge in high risk activities. The findings of Deelchand and Padgett (2009) are supported by the results of this study. As well as the impact of profitability on bank risk is concerned, profitability negatively impacts the risks taken by banks. In other words, highly profitable banks in this study take less risk than the ones which are less profitable. This can be explained by the argument that high profitability is a symbol of sound monitoring and firm procedures, so the banks involve themselves in lower risk activities. Here results are supported by the findings of Tan (2013).

\section{Table 3: SUR Regression of Risk Equation with NPLGL as dependent variable}

\begin{tabular}{lll}
\hline Variable & Coefficient & SE \\
\hline TCTR & 0.1354 & 0.0959 \\
NIM & $-1.4580^{* * *}$ & 0.4156 \\
NLTA & -0.1069 & 0.0685 \\
SIZE & $2.0122^{* *}$ & 0.8960 \\
ROAA & $-1.6374^{* * *}$ & 0.5652 \\
No. of observations & 45 & \\
Parameter & 5 & \\
RMSE & 7.0421 & \\
R Square & 0.7259 & \\
Chi Sq & $135.16^{* * *}$ & \\
\hline
\end{tabular}

$* * * * *, *$ Significant at the $1 \%, 5 \%$, and $10 \%$ levels

This research also estimates the impact of capital regulation on the risks of conventional banks. Table 4 shows the results of capital regulations and other variables affecting the risks of the conventional banks. It shows no significant relationship between capital regulations and either proxy of bank risk. This is consistent with its absence of impact on Islamic banks. It can be concluded that capital regulations do not affect the risks of either Islamic or conventional banks. 
Table 4: SUR Regression of Risk Equation of Conventional Banks

\begin{tabular}{lllll}
\hline & \multicolumn{2}{c}{ LLPNIR } & \multicolumn{2}{c}{ NPLGL } \\
\cline { 2 - 5 } & Coefficient & SE & Coefficient & SE \\
\hline TCTR & -0.54855 & 0.7968 & 0.0538 & 0.0741 \\
NIM & $17.1968^{* * *}$ & 4.0160 & $-1.4745^{* * *}$ & 0.3796 \\
NLTA & 0.5449 & 0.6375 & $-0.2091^{* * *}$ & 0.0590 \\
SIZE & -7.9810 & 5.8065 & $1.1458^{* *}$ & 0.5618 \\
ROAA & $-24.0923^{* * *}$ & 3.3527 & -2.0797 & 0.3205 \\
No. of observations & 258 & & 249 & \\
Parameter & 5 & & 5 & \\
RMSE & 90.877 & & 8.3465 & \\
R Square & 0.1438 & & 0.3281 & \\
Chi Sq & $60.66^{* * *}$ & & $136.77^{* * *}$ & \\
\hline
\end{tabular}

$* * *, * *, *$ Significant at the $1 \%, 5 \%$, and $10 \%$ levels

This study concludes that capital regulations do not curb the risk of Islamic banks. Study results highlighted the inability of the capital regulations to reduce the risks in the Islamic banks of Pakistan. One possible explanation of this result may be those banks which keep capital ratios above the minimum capital requirements are not affected by such capital restrictions. These banks usually have their own capital and risktaking points, an idea advocated by Maji and De (2015). As both Islamic and conventional banks in Pakistan usually maintain Total Capital to Total Risk Adjusted ratio well above the 8 per cent and 10.5 per cent required by Basel II and Basel III respectively, capital regulations do not affect the risk they take.

\subsection{Impact of Capital Regulations on Bank Efficiency}

Table 5 explains the impact of capital regulations on the NIM (a proxy of operational efficiency) for Islamic banks. Bank capital is shown to have a positive and significant effect on bank efficiency. Capital regulations have enhanced the operating efficiency of Islamic banks in this study, rejecting H2A. The findings of Pessarossi and Weill (2015) similarly report a positive effect on Chinese banks. The significant negative coefficient of bank risk shows that bank risk negatively affects bank efficiency. This means banks which take greater risk have less efficiency. As LLPNIR increases, efficiency decreased due to either poor monitoring of loans from bad management or unavoidable external events making it difficult to reduce these loans. These findings support H3A as argued by the bad luck hypothesis. These findings are consistent with those reported by Tan and Floros (2013). 
Table 5: SUR Regression of Efficiency Equation with NIM as dependent variable

\begin{tabular}{llc}
\hline Variable & Coefficient & SE \\
\hline TCTR & $0.0943^{* * *}$ & 0.0301 \\
LLPNIR & $-0.0346^{* * *}$ & 0.0125 \\
NLTA & -0.0088 & 0.0260 \\
SIZE & 0.4176 & 0.3134 \\
ROAA & 0.1720 & 0.1167 \\
No. of observations & 45 & \\
Parameter & 5 & \\
RMSE & 1.5421 & \\
R Square & 0.1619 & \\
Chi Sq & $27.11^{* * *}$ & \\
\hline
\end{tabular}

$* * * * *, *$ Significant at the $1 \%, 5 \%$, and $10 \%$ levels

In this study CIR is used as a proxy of cost inefficiency whose high value is a signal of high inefficiency or low value of low efficiency. Table 6 shows that capital regulations do not affect the cost inefficiency of Islamic banks, thus we reject $\mathrm{H}_{2 \mathrm{~A}}$. We know the impact of risk on the inefficiency of Islamic banks is negative as the sign of the LLPNIR ratio is negative and reaches statistical significance. This shows that Islamic banks in our sample which possess high risks also have high efficiency. The impact of bank risk is positive on bank cost efficiency. Size negatively affects bank inefficiency. This result explains that the big banks are more efficient than the smaller ones. One reason can be size that allows big banks to be more diversified in loaning and deposit deployment. The findings of $\mathrm{Vu}$ and Nahm (2013) also report a positive relationship between size and efficiency. It is also evident in Table 6 that the effect of profitability on bank inefficiency is negative and highly significant. This means that banks with high profit are more efficient than their less profitable counterparts. Findings of Hassan (2006) also report a positive relationship between the profitability and efficiency. 


\section{Table 6: SUR Regression of Efficiency Equation with CIR as dependent variable}

\begin{tabular}{lll}
\hline Variable & Coefficient & SE \\
\hline TCTR & -0.1789 & 0.3049 \\
LLPNIR & $-1.1075^{* * *}$ & 0.1036 \\
NLTA & -0.4064 & 0.2580 \\
SIZE & $-6.4071^{* * *}$ & 3.1343 \\
ROAA & $-29.2409^{* * *}$ & 1.1431 \\
No. of observations & 45 & \\
Parameter & 5 & \\
RMSE & 15.3913 & \\
R Square & 0.9485 & \\
Chi Sq & $993.79^{* * *}$ & \\
\hline
\end{tabular}

$* * * * *, *$ Significant at the $1 \%, 5 \%$, and $10 \%$ levels

Table 7 reports the impact of capital regulations on the efficiency of conventional banks. They increase operational efficiency, as represented by NIM, and have no effect on the cost efficiency, as represented by CIR. Results show no difference in the effect of capital regulations on operational and cost efficiency in the case of Islamic and conventional banks. However, the impact of risk, liquidity and size is different in the case of conventional banks. From the results of Tables 6 and 7, it is clear there is little difference in the impact of capital regulations on the efficiency of conventional and Islamic banks. Capital regulations increase the pure operational efficiency of both Islamic and conventional banks, while it does not affect the cost efficiency in either type of bank. These results support the findings of Errico and Farahbaksh (1998), who also report the equivalent treatment of Islamic and conventional banks by the Basel accord.

Table 7: SUR Regression of Efficiency Equation of Conventional Banks

\begin{tabular}{lllll}
\hline & \multicolumn{2}{c}{ CIR } & \multicolumn{2}{c}{ NIM } \\
\cline { 2 - 5 } & Coefficient & SE & Coefficient & SE \\
\hline TCTR & $0.1063^{* * *}$ & 0.0097 & -0.0909 & 0.2988 \\
LLPNIR & $0.0045^{* * *}$ & 0.0008 & 0.0799 & 0.0255 \\
NLTA & $0.0234^{* * *}$ & 0.0079 & -0.1681 & 0.2346 \\
SIZE & $0.5982^{* * *}$ & 0.0620 & -2.6646 & 1.8244 \\
ROAA & 0.4066 & 0.0451 & $-15.2169^{* * *}$ & 1.3224 \\
No. of observations & 258 & & 258 & \\
Parameter & 5 & & 5 & \\
RMSE & 45.01047 & & 1.44397 & \\
R Square & 0.3846 & & 0.3976 & \\
Chi Sq & $165.65^{* * *}$ & & $343.87^{* * *}$ & \\
\hline
\end{tabular}

$* * * * *, *$ Significant at the $1 \%, 5 \%$, and $10 \%$ levels 
This study concludes that Basel capital regulations treat operating and cost efficiency differently. It has enhanced the operating efficiency but has no effect on the cost efficiency of Islamic banks in this sample.

\subsection{The Capital Equation}

The result for the impact of different variables on the Islamic bank regulatory capital ratio is reported in Table 8 . Results of the study prove that bank risk does not affect the bank capital of the Islamic banks rejecting H1A. The relationship between bank efficiency and bank capital ratio is positive and highly significant. The results reject H2A. Here results are in line with the work of Ahmad, Ariff \& Skully (2008). The findings of this study demonstrate that banks having low liquidity normally have high capital ratios. This phenomenon explains the fact that Islamic banks in the sample of this study are highly capitalized as almost all of Islamic banks have capital ratio above the recommended ratio, so in order to maintain their capital, they sacrifice their liquidity. The results of this study also indicate as bank size increases, bank capital decrease and vice versa. In other words, large banks have low capital ratios. One possible justification could be that size allows the banks easy access to capital market. This allows big banks to hold less capital ratio than their smaller counterparts. The same justification can be put forward for the negative impact of profitability on the bank capital.

Table 8: SUR Regression of Capital Equation with TCTR as dependent variable

\begin{tabular}{llc}
\hline Variable & Coefficient & SE \\
\hline LLPNIR & -0.0568 & 0.0603 \\
NIM & $2.0299^{* * *}$ & 0.6487 \\
NLTA & $-0.3935^{* * *}$ & 0.1046 \\
SIZE & $-7.2051^{* * *}$ & 0.9789 \\
ROAA & $-1.8481^{* * *}$ & 0.4903 \\
No. of observations & 45 & \\
Parameter & 5 & \\
RMSE & 7.0421 & \\
R Square & 0.7259 & \\
Chi Sq & $135.16^{* * *}$ & \\
\hline
\end{tabular}

$* * * * *, *$ Significant at the $1 \%, 5 \%$, and $10 \%$ levels

The results of this study suggest that risk taking does not affect the regulatory capital of Islamic banks, while efficiency has positive effect on the capital of Islamic banks in the sample. This indicates that efficient banks 
are highly capitalized. This could be because high efficiency allows banks extra income to maintain high capital ratios to overcome the possibility of bankruptcy.

\subsection{Impact of Capitals Regulations on Risk before and after Global Financial Crisis}

This research also compares the impact of capital regulations on the risks of Islamic banks before and after the Global Financial Crisis in Table 9. Capital regulations positively impact bank risk before the crisis and this effect is no longer significant after the crisis. Although Pakistani banks were not affected by the Global Financial Crisis due to low share in international financial markets, Pakistani banks might have maintained their regulatory capital ratio far above the required ratio as a precautionary measure.

Table 9: SUR Regression of Risk before and after Global Financial Crisis

\begin{tabular}{lllll}
\hline & \multicolumn{2}{c}{ Before Crisis } & \multicolumn{2}{c}{ After Crisis } \\
& Coefficient & SE & Coefficient & SE \\
TCTR & $0.5249^{* *}$ & 0.2354 & -0.7400 & 0.4688 \\
NIM & $-2.7660^{* * *}$ & 0.7112 & -3.026363 & 2.9359 \\
NLTA & 0.1008 & 0.2173 & -.4930837 & 0.3616 \\
SIZE & $12.8411^{* * *}$ & 3.5206 & -9.782909 & 6.0795 \\
ROAA & 0.1758 & 0.5630 & $-8.309054^{* * *}$ & 4.6926 \\
No. of observations & 16 & & 29 & \\
Parameter & 5 & & 5 & \\
RMSE & 6.650437 & & 16.49246 & \\
R Square & 0.4719 & & .3387 & \\
Chi Sq & $32.12^{* * *}$ & & $22.73^{* * *}$ & \\
\hline
\end{tabular}

According to the findings of this study there is a significant difference in the effect of capital regulations on bank risk before and after the financial crisis. Capital regulations have enhanced the bank risks before crisis while it has no effect on bank risk after the crisis. This insignificant effect of capital regulations after the crisis points towards the ineffectiveness of capital regulations in post crisis period.

\subsection{Impact of Capital Regulation on Efficiency before and after Global Financial Crisis}

Table 10 compares and reports on the impact of capital regulation on Islamic bank efficiency before and after the Global Financial Crisis. According to the results reported in Table 10 there is no difference in the 
impact of capital regulations on bank efficiency before and after the crisis. The Basel Capital regulations have enhanced the operational efficiency in both time periods.

\section{Table 10: SUR Regression of Efficiency before and after Global Financial Crisis}

\begin{tabular}{lcccc}
\hline & \multicolumn{2}{c}{ Before Crisis } & \multicolumn{2}{c}{ After Crisis } \\
& Coefficient & SE & Coefficient & SE \\
\hline TCTR & $0.1620^{* *}$ & 0.0650 & $0.0722^{* *}$ & 0.0281 \\
LLPNIR & $-0.2199^{* * *}$ & 0.0565 & -0.0117 & 0.0113 \\
NLTA & 0.0291 & 0.0608 & -0.0315 & 0.0215 \\
SIZE & $3.1367^{* * *}$ & 1.1372 & -0.4597 & 0.3587 \\
ROAA & 0.1189 & 0.1582 & $0.8476^{* * *}$ & 0.2659 \\
No. of observations & 16 & & 29 & \\
Parameter & 5 & & 5 & \\
RMSE & 1.887688 & & 1.040119 & \\
R Square & 0.2484 & & 0.3882 & \\
Chi Sq & $23.18^{* * *}$ & & $27.02^{* * *}$ & \\
\hline
\end{tabular}

This study concludes that due to capital regulations, operational efficiency is improved both before and after the Global Financial Crisis time periods. Although the effects of the Global Financial Crisis were felt worldwide, and Pakistan is no exception to this, there was no visible effect of the crisis on the efficiency of Islamic banks in Pakistan. This may be due to the low share of Pakistani Islamic banks in international financial markets.

\section{Policy Implications}

The findings of this study will help the State Bank of Pakistan assess the effectiveness of the Basel capital regulations in terms of risk reduction and efficiency enhancement of the Islamic banks, particularly the overall banking sector generally. Ineffectiveness of the Basel capital regulations with respect to risk taking of Islamic banks demands for different capital requirements or tool for Islamic banks. The lack of consensus of the effect of capital regulations on Islamic bank's efficiency also supports the argument of separate capital regulations or mechanisms for Islamic banks.

The State Bank of Pakistan implemented the Basel Accords to align itself with the international community, however the ineffectiveness of the Basel capital regulations with respect to risk reduction of both Islamic and conventional banks points towards formulating regulations according to one's environment. Though it is a good idea to comply international regulations, nevertheless regulators should look at their country's specific 
culture, demographics, circumstances and financial sector needs before implementing the regulations. Dissimilar effect of the Basel capital regulations with respect to risk and efficiency of both Islamic and conventional banks demands for treatment of risk and efficiency differently i.e. making different regulations to enhance efficiency and risk reduction.

\section{Conclusion}

This study investigates and compares the interrelationships between risk, efficiency and bank capital of commercial banks of Pakistan (Islamic and conventional) from 2003 to 2015. By employing Zellner's (1962) SUR approach, results indicate that capital regulations have no impact on Islamic banks risks. However, where the effect of capital regulations on bank efficiency is concerned, the study reports mixed findings. These capital regulations have increased the pure operational efficiency; however, the cost efficiency of Islamic banks neither increased nor decreased during different capital regulations regimes. This study finds no difference in the impact of regulatory capital requirements on risk and efficiency of Islamic and conventional banks. With regards to the effect of capital regulations on bank risk before and after the Global Financial Crisis, there is major difference in the effect of capital regulations on bank risk before and after the Global Financial Crisis, while the effect of capital regulations on bank efficiency remains same before and after the crisis. 


\section{References}

Ahmad, R., Ariff, M., \& Skully, M. J. (2008). The determinants of bank capital ratios in a developing economy. Asia-Pacific Financial Markets, 15(3-4), 255-272.

Alam, N. (2013). Impact of banking regulation on risk and efficiency in Islamic banking. Journal of Financial Reporting and Accounting, 11(1), 29-50.

Altunbas, Y., Liu, M. H., Molyneux, P., \& Seth, R. (2000). Efficiency and risk in Japanese banking. Journal of Banking E Finance, 24(10), 1605-1628.

Altunbas, Y., Carbo, S., Gardener, E. P., \& Molyneux, P. (2007). Examining the relationships between capital, risk and efficiency in European banking. European Financial Management, 13(1), 49-70.

Ashraf, B. N., Arshad, S., \& Hu, Y. (2016). Capital regulation and bank risktaking behavior: Evidence from Pakistan. International Journal of Financial Studies, 4(3), 1-20.

Awan, A. G. (2009). Comparison of Islamic and conventional banking in Pakistan. Proceedings 2nd CBRC, Lahore, Pakistan, 1-36.

Awdeh, A., El-Moussawi, C., \& Machrouh, F. (2011). The effect of capital requirements on banking risk. International Research Journal of Finance and Economics, 66, 133-146.

Ayub, H., \& Javeed, A. (2016). Impact and implications of capital adequacy ratio on the financing behaviour: Evidence from Islamic banks in Pakistan. Journal of Islamic Business and Management, 6(1), 19-40.

Baldwin, R., Cave, M., \& Lodge, M. (2012). Understanding regulation: theory, strategy, and practice. Oxford University Press, Oxford, UK.

Bashir, A., \& Hassan, A. (2017). Interrelationship among basel capital regulation, risk, and efficiency in pakistani commercial banks. Business E Economic Review, 9(2), 165-186.

Barth, J.R., Caprio, G., \& Levine, R. (2006). Rethinking Bank Regulation: Till Angels Govern. Cambridge University Press, Cambridge, UK. 
Barth, J. R., Caprio Jr, G., \& Levine, R. (2008). Bank regulations are changing: For better or worse? Comparative Economic Studies, 50(4), 537-563.

Barth, J. R., Lin, C., Ma, Y., Seade, J., \& Song, F. M. (2013). Do bank regulation, supervision and monitoring enhance or impede bank efficiency? Journal of Banking E Finance, 37(8), 2879-2892.

Berger, A. N., \& DeYoung, R. (1997). Problem loans and cost efficiency in commercial banks. Journal of Banking E Finance, 21 (6), 849-870.

Bitar, M. (2014). Banking regulation, stability and efficiency of Islamic banks: What works best? A comparison with conventional banks (Doctoral dissertation, Université de Grenoble, Grenoble, France). Retrieved from https:/ / tel.archives-ouvertes.fr/tel-01246172/document

Bouheni, F. B. (2013). The effects of supervision on banking performance: European evidence. In Proceedings of the International conference "Governance and Control in Finance and Banking: A New Paradigm for Risk and Performance", Paris, France, April (pp. 18-19).

Chortareas, G. E., Girardone, C., \& Ventouri, A. (2012). Bank supervision, regulation, and efficiency: Evidence from the European Union. Journal of Financial Stability, 8(4), 292-302.

Das, A., \& Ghosh, S. (2004). Risk, capital and operating efficiency: Evidence from Indian public sector banks. Indian Journal of Economics and Business, 1(3), 147-164

de Guevara, J. F., Maudos, J., \& Pérez, F. (2007). Integration and competition in the European financial markets. Journal of International Money and Finance, 26(1), 26-45.

Deelchand, T., \& Padgett, C. (2009). The relationship between risk, capital and efficiency: Evidence from Japanese cooperative banks. ICMA Centre in Finance Working Paper, 09-12.

Delis, M. D., Molyneux, P., \& Pasiouras, F. (2011). Regulations and productivity growth in banking: Evidence from transition economies. Journal of Money, Credit and Banking, 43(4), 735-764. 
Dumičić, M., \& Rizdak, T. (2013). Determinants of banks' net interest margins in Central and Eastern Europe. Financial Theory and Practice, 37(1), 1-30.

Errico, L., \& Farahbaksh, M. (1998). Islamic Banking. Islamic Banking: Issues in Prudential Regulations and Supervision, 98(30), 1-32.

Furlong, F. T., \& Keeley, M. C. (1989). Capital regulation and bank risktaking: A note. Journal of Banking \& Finance, 13(6), 883-891.

Hassan, M. K. (2006). The X-efficiency in Islamic banks. Islamic Economic Studies, 13(2), 49-78.

Hassan, M. K., \& Hussain, M. E. (2006). Basel II and bank credit risk: Evidence from the emerging markets. Networks Financial Institute Working Paper, 10.

Jacques, K., \& Nigro, P. (1997). Risk-based capital, portfolio risk, and bank capital: A simultaneous equations approach. Journal of Economics and Business, 49 (6), 533-547.

Khan, M. A., \& Khan, S. (2007). Financial sector restructuring in Pakistan. The Lahore Journal of Economics, 12(SE), 97-125

Kim, D., \& Santomero, A. M. (1988). Risk in banking and capital regulation. The Journal of Finance, 43(5), 1219-1233.

Maji, S. G., \& De, U. K. (2015). Regulatory capital and risk of Indian banks: A simultaneous equation approach. Journal of Financial Economic Policy, 7(2), 140-156.

Miah, M. D., \& Sharmeen, K. (2015). Relationship between capital, risk and efficiency: A comparative study between Islamic and conventional banks of Bangladesh. International Journal of Islamic and Middle Eastern Finance and Management, 8(2), 203-221.

Nguyen, T. P. T., \& Nghiem, S. H. (2015). The interrelationships among default risk, capital ratio and efficiency: Evidence from Indian banks. Managerial Finance, 41(5), 507-525.

Pasiouras, F., Tanna, S., \& Zopounidis, C. (2009). The impact of banking regulations on banks' cost and profit efficiency: Cross-country evidence. International Review of Financial Analysis, 18(5), 294-302. 
Pessarossi, P. and L. Weill (2015). Do capital requirements affect cost efficiency? Evidence from China. Journal of Financial Stability, 19(6), 119-127.

Podpiera, J. and L. Weill (2008). Bad luck or bad management? Emerging banking market experience. Journal of Financial Stability 4(2), 135-148.

Popovici, M. C. (2014). Measuring banking efficiency by using ROAA and ROAE: Evidence from the European Union. CES Working Papers, (1), 146-153.

Rime, B. (2001). Capital requirements and bank behaviour: Empirical evidence for Switzerland. Journal of Banking \& Finance, 25(4), 789-805.

Reda, I. A., Rjoub, H., \& Alrub, A. A. (2016). The Determinants of banks' profitability under basel regulations: Evidence from Lebanon. International Journal of Economics and Finance, 8(10), 206.

Repullo, R., \& Suarez, J. (2008). The procyclical effects of Basel II. Center for Monetary and Financial Studies Working Paper, 0809.

Sarmiento, M., \& Galán, J. E. (2017). The influence of risk-taking on bank efficiency: Evidence from Colombia. Banco de Espana Working Paper, 1537.

Shrieves, R. E., \& Dahl, D. (1992). The Relationship between risk and capital in commercial banks. Journal of Banking E Finance, 16(2), 439-457.

Stigler, G. J. (1971). The theory of economic regulation. The Bell Journal of Economics and Management Science, 2(1), 3-21.

Sun, L., \& Chang, T.-P. (2011). A comprehensive analysis of the effects of risk measures on bank efficiency: Evidence from emerging Asian countries. Journal of Banking E Finance, 35(7), 1727-1735.

Tan, Y. (2013). Essays on the analysis of performance and competitive condition in the Chinese banking industry (Doctoral dissertation, University of Portsmouth, Portsmouth, UK). Retrieved from https://researchportal.port.ac.uk/portal/files/6084408/PhD_the sis_Yong_Tan.pdf 
Tan, Y., \& Floros, C. (2013). Risk, capital and efficiency in Chinese banking. Journal of International Financial Markets, Institutions and Money, 26, 378-393.

Triki, T., Kouki, I., Dhaou, M. B., \& Calice, P. (2017). Bank regulation and efficiency: What works for Africa? Research in International Business and Finance, 39(Jan), 183-205.

Vianney, K. J. M. (2013). The relationship between regulation and financial performance of Rwanda commercial banks. (MBA Research Project, University of Nairobi, Nairobi, Kenya). Retrieved from http://chss.uonbi.ac.ke/sites/default/files/chss/EXTERNAL\%2 OEXMINERS.pdf

Vu, H., \& Nahm, D. (2013). The determinants of profit efficiency of banks in Vietnam. Journal of the Asia Pacific Economy, 18(4), 615-631.

Zellner, A. (1962). An efficient method of estimating seemingly unrelated regressions and tests for aggregation bias. Journal of the American Statistical Association, 57(298), 348-368. 